\title{
Analysis of Maize Marketing; The Case of Farta Woreda, South Gondar Zone, Ethiopia
}

\author{
Walelgn Yalew Beadgie ${ }^{1}$, Lemma Zemedu ${ }^{2}$ \\ ${ }^{1}$ Department of Agricultural Economics, University of Gondar, Gondar, Ethiopia \\ ${ }^{2}$ Department of Agricultural Economics, Haramaya University, Haramaya, Ethiopia \\ Email address: \\ walelgnyalew@gmail.com (W. Y. Beadgie), zemedul@yahoo.com (L. Zemedu) \\ To cite this article: \\ Walelgn Yalew Beadgie, Lemma Zemedu. Analysis of Maize Marketing; The Case of Farta Woreda, South Gondar Zone, Ethiopia. \\ International Journal of Agricultural Economics. Vol. 4, No. 4, 2019, pp. 169-180. doi: 10.11648/j.ijae.20190404.15
}

Received: March 4, 2019; Accepted: June 3, 2019; Published: July 11, 2019

\begin{abstract}
Maize is widely grown as a major food and cash crop in Southern Gondar zone, faces with problems as seasonal supply, price fluctuations, and inadequate information on production, marketing and consumption. These problems are more acute in urban areas too. Effective crop marketing is essential for efficient agricultural and rural development, particularly with regard to continued increase in crop production and producer's income. The research tried to analyze the marketing system of maize in farta woreda with specific objective of identifying determinant factors affecting house hold participation decisions of maize market and determining volume of maize market supply in the study area. Primary data was collected from 154 maize producers. Based on multi-stage random sampling procedures both probability sampling and non-probability sampling procedures were followed to select six Peasant Associations. Structured interview schedule and questionnaire was used for collecting the essential quantitative and qualitative data from the sampled farmer respondents. To generate qualitative data, field observations and informal interview with key informants were conducted. The quantitative data was analyzed using descriptive statistical tools and Tobit model was employed to estimate the factors jointly affecting maize market participation decisions' and determinants of volume of maize supply of households. Farmers' decision to participate on maize market in Farta woreda was significantly but negatively influenced by sex whereas age, time of sale, area of maize, oxen number, access to market information, credit access and membership in primary cooperatives positively influenced maize market participation $\&$ extent of participation. Generally, maize marketing system in the study area observed to be inefficient and underdeveloped. Thus, marketing system development interventions should be aimed at addressing both maize production technological gaps and marketing problems.
\end{abstract}

Keywords: Tobit Model, Maize Marketing, Decision \& Level of Participation

\section{Introduction}

\subsection{Background}

The share of agriculture to Ethiopian economy during the F.Y $2012 / 13$ was 42.7 percent. The sector contributed 31.2 percent to GDP growth rate and grew by 7.1 percent in comparison with the 4.9 percent growth recorded in the preceding year. This was due to a high increase in crop production which improved from 5 percent to 8.2 percent as compared to previous year performance and contributing about 26 percent to GDP growth and 80 percent to agriculture growth [1].

As under rain-fed agriculture, an average family of 6 persons requires around 2.5 to 2.8 hectares to meet annual household food requirements. Thus, it can be seen from the size of farms that the vast majority of Ethiopia's small-holder farmers are dependent, at least for a certain period of the year, on purchased food. Despite the production challenges, agriculture accounts for 43 percent of GDP and 90 percent of exports. Cereal production which dominates Ethiopian agriculture has increased significantly over recent years, and production estimates for 2010 stand at 18.8 million metric tons, which is more than double the production averages in 2000 and 2003 [2].

In the country, Cereal products are also the major stable food crops. Out of the total grain crop area, $78.17 \%$ $(9,601,035.26$ hectares) was under cereals. Teff, maize, 
sorghum and wheat took up 22.23\% (about 2,730,272.95 hectares), 16.39\% (about 2,013,044.93 hectares), 13.93\% $(1,711,485.04$ hectares $)$ and $13.25 \%(1,627,647.16$ hectares $)$ of the grain crop area, respectively. Cereals contributed $84.96 \%$ (about 196,511,515.46 quintals) of the grain production. Maize, teff, wheat and sorghum made up $26.63 \%$ $(61,583,175.95$ quintals $), 16.28 \%(37,652,411.66$ quintals $)$, $14.85 \%(34,347,061.22$ quintals $)$ and $15.58 \%(36,042,619.65$ quintals) of the grain production, in the same order [3].

In the Amhara region; agriculture is the backbone of the regional economy; contributing for about $73 \%$ of the regional GDP and more than $90 \%$ of the total employment [4]. Out of the total land size of the region of land had been used for the production of cereals, 3,254,156.12 hectares; the estimated production was about $59,051,697.91$ quintals at yield of 16.75 of these 494,625 hectares was covered by maize contributing $13,387,027.21$ quintals. Cereals account for more than 80 percent of cultivated land and 85 percent of total crop production. The principal cereal crops in the Amhara region are teff, barley, wheat, maize, sorghum and finger millet. Pulses and oil crops are the other major categories of field crops. Based on the report of BOARD, East Gojam, west Gojam, South Gondar zones and Farta woreda district are the major cereal producing areas in the region [5].

In South Gondar zone; agriculture is the backbone of the economy. Out of $370,138.47$ hectares of cereal crops, $6,450,970.22$ quintal is produced of which $36,417.32$ hectares was covered by maize with total production of $860,616.98$ quintals [6]. Farta woreda district is one of the 105 woredas in the Amhara region that can grow diverse annual and perennial crops required for household consumption and for the market. The major cereals crops grown in the woreda include maize, teff, wheat, sorghum, finger millet and barley which are dominantly produced in the woreda [7]. Production of maize by smallholder farmers of the woreda is mainly for market in the area. The land area covered by maize and wheat in the woreda was 9065.5 and 7239 hectares respectively. The woreda produced 132,112.6 and 120,197 quintals of maize and wheat respectively.

\subsection{Statement of the Problem}

Supply of agricultural crop in the study area is subjected to seasonal variation where surplus supply at harvest and surplus supply later on is the main feature. The nature of the product on the one hand and lack of properly functioning marketing system on the other, often resulted in lower producers' price.

The study area comprises mixed farming zones where crops are grown for food and cash. Among producing crops wheat, barley, teff, finger millet and maize are crops farmers usually market them for their cash purposes, Hence different studies have been conducted in different areas about marketing aspects of these crops, for example teff and wheat were conducted by Urgessa, (2011) in Halaba district, marketing system and the reasons for high price increase by taking three major staple food grains in Ethiopia: maize, wheat and teff by Asfaw and Myers (2007), Demeke, Alemu et al., (2007), Dorosh and
Subran, (2007). However, marketing aspects of maize crops were not undertaken in the study area which have potential production volume and marketability problem of maize at all levels and the socio economic variable change and their influence on the quantity supplied of maize still unresolved in the study area. This made the undertaking of marketing analysis of maize crops in the woreda good looking. Therefore, the study was designed to address the prevailing information gap on the subject and contribute to proper understanding of the challenges and assist in developing improved market development strategies to benefit of smallholder farmers, traders, and other market participants.

\subsection{Objectives of the Study}

\subsubsection{General Objective of the Study}

The overall objective of this study is to analyze the determining factors of decision \& extent of maize market participation in farta woreda.

\subsubsection{Specific Objectives of the Study}

The study is aimed at identifying the significant factors affecting the level of maize market participation and participation decision of the target populations in the study area with the following specific objectives.

1. To identify factors affecting house hold participation decisions of maize market.

2. To identify factors determining volume of maize marketed surplus in the study area.

\subsection{Research Questions}

1. What are the factors affecting house hold participation decision of maize market in the woreda?

2. What are factors determining volume of maize marketed surplus in the study area?

\subsection{Significance of the Study}

This study focused on the factors affecting maize market participation decision \& extent of participation in Farta woreda. The information is expected to assist market participants to understand the supply potential and analyze the performance of maize marketing activities which could serve as a major input to formulate appropriate marketing policies and strategies in Farta woreda by identifying interventions that improve efficiency of the marketing system. The study can also serve as an additional source to conduct detailed studies by identifying research agenda.

Besides, it provided valuable information to formulate marketing development programs, pinpoint constraints and recommend policy implications. Furthermore, the study also identified an additional input for further related studies.

\subsection{Scope and Limitation of the Study}

This study was carried out in South Gondar zone of Amhara region particularly in Farta woreda. Due to time and budget limitations and accessibility problems, the study was conducted only in 6 kebeles. The study was restricted to the 
marketing analysis of maize production. The study was focused on factors affecting maize market participation \& maize supply. Furthermore, the market actors involved directly or indirectly in maize marketing was examined to generate relevant data.

\section{Methodology}

\subsection{Description of the Study Area}

The study was conducted in Farta district rural households, South Gondar Zone, Amhara National Regional State. Amhara National Regional State is located at $9^{\circ}$ and $13^{\circ} 45^{\prime}$ north latitude and $36^{\circ}$ and $13^{\circ} 45^{\prime}$ east longitude. The land area covers about $170,752 \mathrm{Km}^{2}$. It is bordered with Afar in the east, Benishangul Gumuz in the south western, Oromia in the south and South western, Tigray in the north and with the Sudan in the west. Farta district is bordered on the South by Misraq Este, on the west by Fogera, on the north by Ebenat, and on the east by Lay Gayint. Towns in the District include Gasay and Kimir Dingay. The town of Debre Tabor is surrounded by Farta District administrative kebeles. The District specific location lies between $11^{\circ} 32^{\prime}$ to $12^{\circ} 03^{\prime}$ latitude and $37^{\circ} 31^{\prime}$ to $38^{\circ} 43^{\prime}$ 'longitude [8].

Based on the 2012 national census conducted by the Central Statistical Agency of Ethiopia, this District has a total population of 264,273 with male 133,923 and female 130,349 With an area of 1,070.77 square kilometers, Farta has a population density of 246.81 , which is greater than the Zone average of 145.56 persons per squarekilometer [9]. A total of 49,986 households were counted in this district, resulting in an average of 4.64 persons to a household, and 48,465 housing units. Largest ethnic group reported in Farta was the Amhara (99.95\%), Amharic was spoken as a first language by $99.96 \%$, and $99.57 \%$ of the population practiced Ethiopian Orthodox Christianity.

The district is characterized under Woina Dega agroecological zone. The mean maximum temperature of Farta district is $21^{\circ} \mathrm{C}$ from February to May. The mean minimum temperature is $9.6^{\circ} \mathrm{C}$ from June to January while the mean annual temperature of the woreda is $15.5^{\circ} \mathrm{C}$.

In terms of topography, $45 \%$ of the total area is gentle slope, while flat and steep slope lands account for $29 \%$ and $26 \%$, respectively. The District has an altitude that varies between 1900 to 4035 meters above sea level [10]. In terms of land use pattern, an estimated $65 \%$ of the area is cultivated and planted with annual and perennial crops, while area under grazing and browsing, forests and shrubs, settlements and wastelands account for about 10, $0.6,8$ and $17 \%$ respectively. $50 \%, 30 \%$ and $20 \%$ of the soil are brown, red and black respectively. The district has a total livestock population of 432,822 [11].

In Farta district, agriculture contributes much to meet major objectives of farmers such as food supplies and cash needs. The sector is characterized by its rainfed and subsistence nature [12]. The study area comprises mixed farming zones where crops are grown for food and cash, and livestock are kept for complementary purpose, as a means of security during food shortage, and to meet farmerse cash needs. The dominant crops grown in the district are barley, wheat, teff, sorghum, maize; field beans, peas, chickpeas, oil crops and root and tuber crops like potato, etc. Field beans, teff and wheat are also market crops for cash needs in addition to maize.

The map location of the study area is as follows.

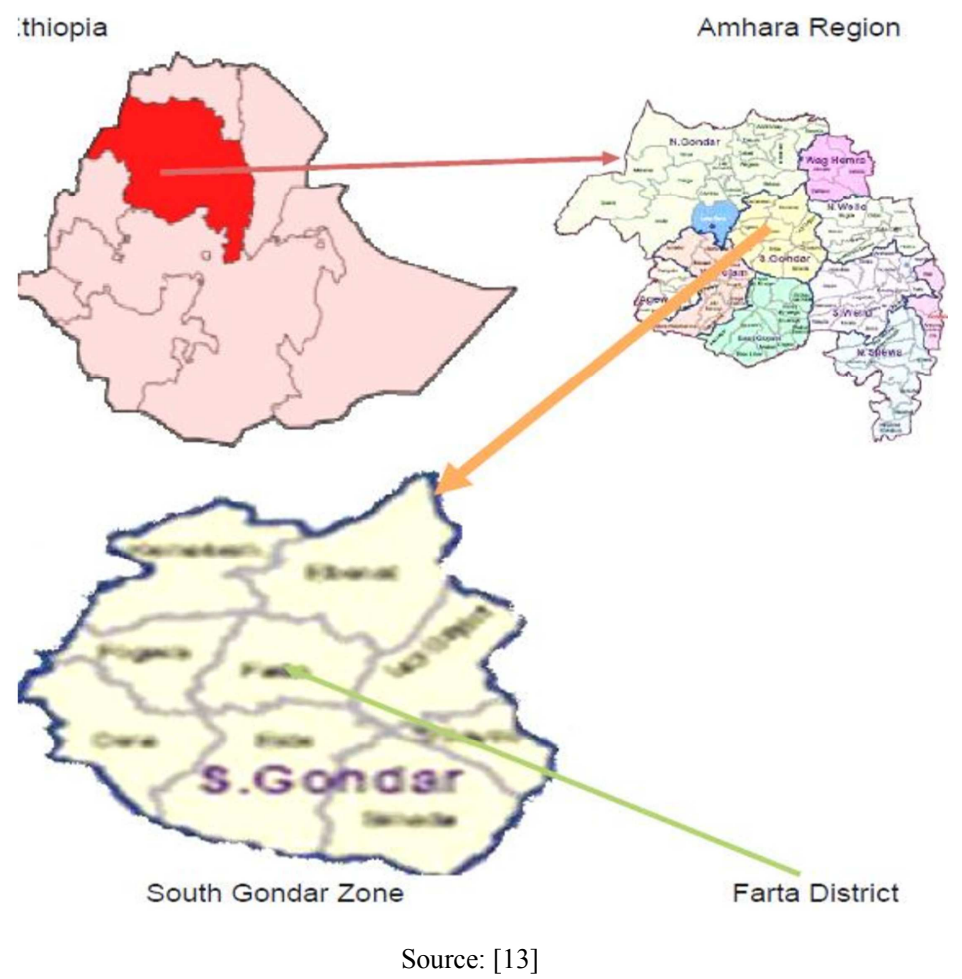

Figure 1. Geographical location of study area. 


\subsection{Data Source and Requirements}

In this study both the primary and secondary data were collected. Primary data source was smallholder farmers randomly selected from six different rural Pas. In this study primary data were collected focusing on prices, volume and marketing functions, facilities and services, production and marketing costs, production and marketing support services, and other socio-economic variables of maize producers.

Secondary data: these are data which were collected reviewing documents of secondary sources namely Farta woreda office of Agriculture and Rural Development, Office of Small Scale Trade and Transport, books of Central Statistical Authority (CSA), and Bureau of Agriculture and Rural Development, Bureau of Finance and Economic Development of Amhara Region whenever necessary.

\subsection{Sampling Procedures}

For the study of maize marketing, Farta District was selected purposively. To develop sampling frame for the study, Multi-stage sampling technique was used. Under Multi-stage sampling, random sampling from probability sampling techniques and convenient sampling from nonprobability sampling techniques were utilized. The sample frame of the study was the list of the targeted population of households' PAs in Farta District. Due to time and budget limitations and accessibility problems, the study was conducted only in 6 PAs purposively.

Multi-stage random sampling procedure was employed to select potential maize producer households. In the first stage since PAs in the study area surrounds the capital city of South Gondar Zone, "DebreTabor" taking as a center based on distance and infrastructural facilities, potential maize producer PAs from the District was stratified depending on farness and nearby through stratified sampling method by considering the total number of 41 kebeles in the district

In the second stage, potential maize producers PAs (3PAs from nearby) and (3 PAs from far) were selected using convenient sampling.

And in the third stage using the population list of maize producer farmers from sample PAs, the intended sample size was determined proportionally to population size of maize producer farmers. Then 154 representative households were randomly selected using simple random sampling technique. The sample size is determined by considering the confidence level, the degree of variability and level of precision [14]. The formula used to calculate and determine the sample size is: -

$$
\mathrm{n}=\frac{N}{1+N(e) 2}
$$

Where: $\mathrm{n}$ is the sample size, $\mathrm{N}$ is the population size (total household size) and e is the level of precision. The minimum level of precision is acceptable at $10 \%$. However, for this study $8 \%$ of precision level was used. Based on the number of the total households (9852) in the sampling frame, the formula equated and reached a minimum of 154 respondents to be drawn. Then representative households were randomly selected using probability proportional to sample size (PPS). It is represented in figure 2 as follows.

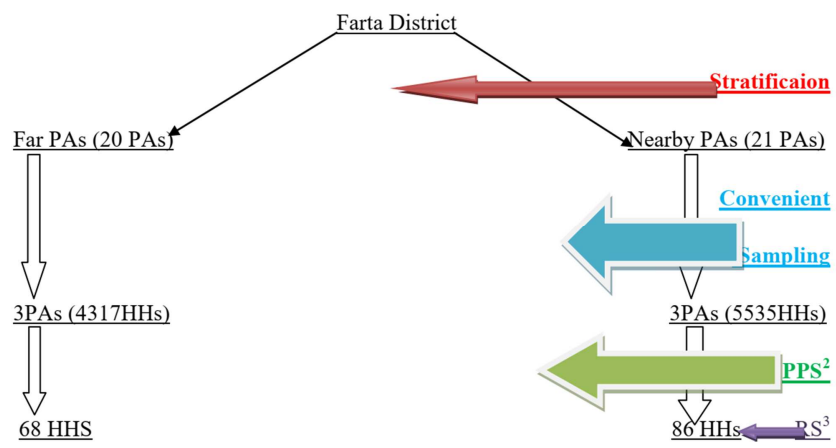

Figure 2. Sampling procedure of the study area.

Source: own sketch summary

${ }^{2} \mathrm{PPS}$ is to mean proportional to population size

${ }^{3} \mathrm{RS}$ is to mean random sampling

Table 1. Distribution of sample households by kebele.

\begin{tabular}{llll}
\hline No & $\begin{array}{l}\text { Name of sample } \\
\text { nearby PAs }\end{array}$ & $\begin{array}{l}\text { Total number of } \\
\text { household heads }\end{array}$ & $\begin{array}{l}\text { Number of sample } \\
\text { household heads }\end{array}$ \\
\hline 1 & Kolay & 1802 & 28 \\
2 & Buro & 2117 & 33 \\
3 & Woriqien & 1616 & 25 \\
\hline & & & \\
\hline \multirow{2}{*}{ No } & Name of sample & Total number of & Number of sample \\
& far PAs & household heads & household heads \\
\hline 1 & Amjaye & 1642 & 26 \\
2 & Imbayiko & 1217 & 19 \\
3 & Genamechawecha & 1458 & 23 \\
& Total & 4317 & 68 \\
Total sample & 6PAs & 9852 & 154 \\
size & & & \\
\hline
\end{tabular}

Source: own computation from Farta Distric, [15]

\subsection{Method of Data Collection}

Smallholder farmers were shown little cooperation unless their concerns were taken care of very seriously. In order to gain their trust, the respondents were carefully informed about the objectives of the survey and the direct and indirect benefits from the research. The data were collected formally by the method of individual interview using pre-tested structured interview schedule questionnaire and informally key informants using checklists. Then five enumerators were given training and briefings on the objective, contents of the interview schedule and were also acquainted with the basic techniques of data gathering and interviewing techniques and on how to approach farmers.

Primary data were collected using of questionnaire, for farmers by the well-equipped enumerators. Primary data were also collected through key informant interviews. Secondary data were gathered to support the information to be collected from primary sources. Secondary data sources were Woreda Office of Agriculture and Rural Development, Woreda Office of Small Scale Trade and Transport, CSA etc. 


\subsection{Method of Data Analysis}

Generally, in this study descriptive statistics and econometric models were employed. To analyze the data SPSS 20 and STATA 12 software program were applied.

\subsection{Descriptive Statistics Analysis}

In this study, data were analyzed using different quantitative and qualitative procedures and methods. The important statistical measures that were used to summarize and categorize the research data are means, percentages and frequencies. Chi-square test for dummy variable and t-test for continuous variable were utilized.

\subsection{Econometric Analysis}

Descriptive statistics often fail to predict the combined effect of the explanatory variables on the dependent variable [16]. Thus, this gap is to be bridged by the help of selecting and using appropriate econometric models. The objective of this study was achieved by employing econometric model to predict the influences of the explanatory variables on the dependent variable. The marketing of maize can be influenced by various set of socio-economic and institutional factors. Modeling households" ${ }^{\text {ec }}$ response towards these influencing factors of decision and extent of market participation of maize would, therefore, become important both theoretically and empirically. For empirical purposes, the participation decision can be framed as a binary choice (participant or not participant), and/or as some continuous dependent variables over a predefined interval or intensity of participation.

Estimation of the earlier type of relationship requires the use of qualitative response models. In this regard, the non-linear probability models, logit and probit models are the possible alternatives. However, several estimation problems arise particularly when Ordinary Least Squares (OLS) regression and linear probability models are employed. The OLS regression technique, when the dependent variable is binary, produces parameter estimates that are inefficient and a heteroscedastic error results in the structure. To alleviate these problems and produce relevant empirical outcomes, the most widely used qualitative response models are the logit and probit models $(\mathrm{ibid})$. The logit and probit models guarantee that the estimated probabilities will lie between the logical limit of 0 and 1 . These two binary outcome models have Sshaped relationship between the independent variables and the probability of an event which addresses the problem with functional form in the linear probability model [17].

If a data set that is used for a regression suffers from selectivity bias, then the regression analysis, for example Ordinary Least Squares (OLS), which computes the effects of some characteristics of this population on other characteristics, will be biased. The objective of this study is to determine the factors affecting participation decision and extent of participation of maize marketing in the study woreda. Hence Heckman has developed a two-step estimation procedures model that corrects for sample selectivity bias. If two decisions are involved, such as participation and volume of supply,
Heckman two step estimation procedures are appropriate. The first stage of the Heckman two-stage model a "participation equation", attempts to capture factors affecting participation decision. This equation is used to construct a selectivity term known as the "inverse Mills ratio" (which is added to the second stage "outcome equation") that explains factors affecting volume of maize supply. The inverse Milles ratio is a variable for controlling bias due to sample selection [18]. If the estimated coefficient of the selectivity term "LAMPDA" is significant then the hypothesis that an unobserved selection process governs the participation equation is confirmed but the hackman selection model result shows that LAMPDA was in significant. This implies that sample selection bias would not be resulted if the maize supply equations would be estimated without considering the discrete decision to participate in maize market and the result is found in the Annexl for the purpose of comparison.

Hence in this study, the Tobit model was employed. This was because, using the tobit model was appropriate to identify the factors affecting the participation and the volume of supply of maize to the market at the same time. Hence Tobit model is superior over other dichotomous regression models in that not only attempts to explain factors influencing the probability of maize market participation by the farm households rather it determines also the intensity of market participation. Strictly dichotomous variable often is not sufficient for examining intensity of adoption, participation etc. In such cases, Tobit model, which has both discrete and continuous part, is appropriate because it handles both the probability and intensity of participation at the same time. Accordingly Tobit model was used.

Model specification: Tobit model: The censored regression (Tobit model) is appropriate when the dependent variable is censored at some upper or lower bound depending on nature of the data available [19], [20]. For censoring at a lower bound (in this case), the model is:

$$
\begin{gathered}
y i *=B O \sum_{i=0}^{N}(\mathrm{BiXi})+\mu \mathrm{i} \text { where } \mu \mathrm{i} \sim(0, \delta 2) \\
Y=y i * \text { if } B o+\sum_{i=0}^{N}(\mathrm{BiXi})+\mu \mathrm{i}>0 \\
Y=0 \text { if } B o+\sum_{i=0}^{N}(\mathrm{BiXi})+\mu \mathrm{i}<0 \\
Y=\max (y i *, 0)
\end{gathered}
$$

Where for the $\mathrm{i}^{\text {th }}$ observation, $\mathrm{y}^{*}$ is an unobserved continuous latent variable and conditional on being above certain limit. $\mathrm{Y}_{\mathrm{i}}=$ is observed market supply of maize marketing for $i^{\text {th }}$ farmer, is a continuous variable measured in quintal $X_{i}=$ is a vector of values on the independent variables, $B_{O}=$ is an intercept $B_{i}=$ is a vector of coefficients and $\mu_{\mathrm{i}}=$ is the error term which is normally distributed with mean 0 and variance $\delta^{2}$. The model parameters were estimated by maximizing the Tobit likelihood function of the 
following form [21], [22].

$$
L=\Pi y *>0 \frac{1}{\delta} \mathcal{F}\left(\frac{\mathrm{Yi}-\mathrm{BiXi}}{\delta} \Pi y * \leq 0 F\left(\frac{-\mathrm{BiXi}}{\delta}\right)\right.
$$

Here $f$ and $F$ respectively are the density function and the cumulative function of $\mathrm{y}^{*}$. $\mathrm{y}^{*} \leq 0$ means that the product over those of I for which $\mathrm{y}^{*} \leq 0$ and $\Pi^{*}>0$ means the product over which $y^{*}>0$. An econometric software known as "STATA 12 " was employed to run the Tobit model. It may not be sensible to interpret the coefficients of a Tobit in the same way as one interprets coefficients in an uncensored linear model [23]. The significant variables do not all have the same impact on the decision and extent of participation of maize market. Hence, one has to compute the derivatives of the estimated Tobit model to predict the effects of changes in the explanatory variables. That is probability and intensity of the participation of maize marketing.

Mcdonald and Moffit, proposed the following techniques to decompose the effects of explanatory variables into decision and intensity effects [24]. Following the method of McDonald and Moffit; the coefficients obtained from Tobit analysis were decomposed to show the effect of changes of the dependent variable $\mathrm{X} i$, in the probability and extent of participation in the marketing channel. This was achieved by differentiating the expectation of the latent variable $\mathrm{y} i *$ on the $\mathrm{X}_{i}$ as follows:

$$
\partial \varepsilon \frac{\left(\frac{y i *}{x i}\right)}{\partial x i}=B i
$$

Thus, the reported Tobit coefficients indicate how a one unit change in an independent variable $x_{i}$ alters the latent dependent variable. Further McDonald and Moffit explained the probability of participation (conditional if $y^{*}>0$ ) of a given marketing channel as:

$$
\partial \varepsilon \frac{y i *}{\partial x i}=X B F(Z)+\partial f(z)
$$

Where $\mathrm{X}$ is a vector of explanatory variables, $\mathrm{F}(\mathrm{z})$ is the cumulative normal distribution of $\mathrm{z}, f(\mathrm{z})$ is the value of the derivative of the normal curve at a given point (i.e., unit density), $\mathrm{z}$ is the $\mathrm{Z}$-score for the area under the normal curve, $\beta$ is a vector of maximum likelihood estimates and the $\delta$ is the standard error of the error term. The change in intensity of market participation with respect to change in an explanatory variable among sellers / for uncensored observation is:

$$
\partial \varepsilon \frac{\left(\frac{y i *}{y i *>0}\right)}{\partial x i}=B i\left(1-\frac{z f(z)}{F(z)}-\left(\frac{f(z)}{F(z)}\right) 2\right)
$$

This indicates how a one-unit change in an independent variable $x_{i}$ affects uncensored observations. The above variables were obtained from the Tobit output of the marketing of maize under study.

\subsection{Conceptual Frameworks of Variables Selected for the Study}

In order to explain farmer's maize market participation, continuous and discrete variables were identified based on economic theories, the findings of different empirical studies and key informant interview. In this study, 16 independent variables and two dependent variables were selected to prove the hypotheses set for this study hoping that they would address the objectives and they are presented in the figure as follows.

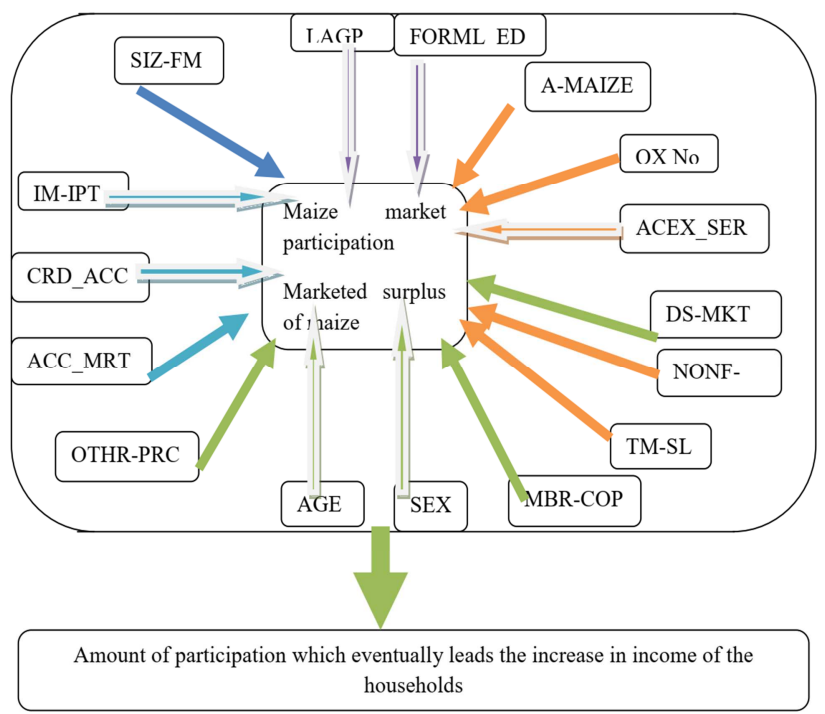

Source: own conceptualization

Figure 3. Conceptual framework of the study.

\section{Result and Discussion}

\subsection{Socio-Economic\& Demographic Characteristics of Farmers}

In an agrarian society, household members are the major source of labor for agricultural activities. The household characteristics such as age, sex, educational levels etc. differ from one household to the others. Sample households were composed of both male headed and female headed household heads. The total sample size of farm respondents handled during the survey was 154 . Out of 154 samples household respondents $13.6 \%$ was female and $86.4 \%$ were male household heads. While according to the survey result the entire sample households were orthodox Christian followers.

Use of improved inputs is the basic factors boosting productions if producer use improved seed and fertilizers, this will increase production and productivity thus, increases the market supply. The survey shown that $8.4 \%$ of sample household heads did not use improved input and did not participate in maize market where as $27.9 \%$ was users of improved inputs but did not participate in the market. 5.8\% of sample household heads were not utilized improved inputs that were participated in the maize market while $57.8 \%$ of sample household heads were utilized improved inputs. According to the chi-square result shown in the survey two groups participant and non participants were found to be significant at $5 \%$ significant level $\left(\chi^{2}=5.729, \mathrm{p}=0.017\right)$ in 
terms of user and non- users of improved inputs used.

The chi- square test also revealed that participants and non participant were found to be significantly different at $1 \%$ significant level $\left(\chi^{2}=149.795, \mathrm{p}=0.000\right)$ in time of sale in such a way that participated household were about $40.3 \%$ who supplied their product to the market immediately after harvest and earn a better price while $23.4 \%$ of them and $36.4 \%$ of non participant were not supplied their product soon.

Access to market information is extremely limited in the Ethiopian maize market. It is assumed that producers who had market information can decide how much to produce and market. However, the survey revealed that only 62.34 per cent of the total sampled households had price information about the nearby market price before they sold their maize while $37.66 \%$ of sample farmers were not informed about market price information.

There was statistical difference among participant and non participant according to their level of information access at $1 \%$ significant level $\left(\chi_{2}=23.123, \mathrm{p}=0.000\right)$. Producers that have access to market information are likely to supply more maize to the market. The survey data result shown that $22.7 \%$ were not accessed to information so that were not participated in the market. The rest of $13.6 \%$ got market information but did not participate in the market. And $14.9 \%$ of sample household heads participated in the market without market information where as $48.7 \%$ of household heads got market information caused them to participate in the market.

The Chi-square test also revealed that participant and non participant sample household heads were significantly different at $5 \%$ significant level $\left(\chi^{2}=5.567, \mathrm{p}=0.018\right)$ in terms of access of credit use. $5.8 \%$ of farmers had Credit access but did not participate, $30.5 \%$ had no access to credit so did not participate in maize market. While $21.4 \%$ of sample farmers had access to credit that were participant of maize market but $42.4 \%$ of household heads were participated in maize market that did not have credit access. The details of these characteristics for the sampled households in the study areas are depicted in Table 2.

Table 2. The proportion characteristics of the sample respondents by market participation.

\begin{tabular}{|c|c|c|c|c|c|}
\hline Variable & Category & Market Non-participant (\%) & Market Participant (\%) & $X^{2}$-value & p-value \\
\hline \multirow{2}{*}{ Sex } & Male & 31.2 & 55.2 & \multirow{2}{*}{0.032} & \multirow{2}{*}{0.859} \\
\hline & Female & 5.2 & 8.4 & & \\
\hline \multirow{2}{*}{ FORML-ED } & Formal & 16.9 & 37.7 & \multirow{2}{*}{0.458} & \multirow{2}{*}{0.498} \\
\hline & Otherwise & 19.5 & 26 & & \\
\hline \multirow{2}{*}{ IM-IPT } & YES & 27.9 & 57.8 & \multirow{2}{*}{$5.729^{* *}$} & \multirow{2}{*}{0.017} \\
\hline & NO & 8.4 & 5.8 & & \\
\hline \multirow{2}{*}{ TM-SL } & Immediately after & $*$ & 40.3 & \multirow{2}{*}{$149.795 * * *$} & \multirow{2}{*}{0.000} \\
\hline & Otherwise & 36.4 & 23.4 & & \\
\hline \multirow{2}{*}{ ACC-MKTI } & YES & 13.6 & 21.4 & \multirow{2}{*}{$23.123^{* * *}$} & \multirow{2}{*}{0.000} \\
\hline & NO & 30.5 & 42.4 & & \\
\hline \multirow{2}{*}{ CRD-ACC } & YES & 5.8 & 21.4 & \multirow{2}{*}{$5.567^{* *}$} & \multirow{2}{*}{0.018} \\
\hline & NO & 30.5 & 42.4 & & \\
\hline \multirow{2}{*}{ ACEX-SER } & YES & 38.8 & 61.7 & \multirow{2}{*}{1.368} & \multirow{2}{*}{0.242} \\
\hline & NO & 2.6 & 1.9 & & \\
\hline \multirow{2}{*}{ MBR-COP } & YES & 20.8 & 51.9 & \multirow{2}{*}{$10.776^{* * *}$} & \multirow{2}{*}{0.001} \\
\hline & NO & 15.6 & 11.7 & & \\
\hline
\end{tabular}

Source: survey result (2016) *stand for zero values, $* * *, * *, *$ are significant at less than $1 \%, 5 \%, 10 \%$ significant level respectively.

The mean characteristics of households by market participation who sold maize to market intermediaries available in the study area are given in Table 3. For the descriptive statistics, sampled households were divided into participants and non-participants of maize marketing. The objective is to assess the differences and similarities among participant and non-participants of maize producers in terms of their demographic and socioeconomic, farm, institutional and market characteristics. Out of 154 households, $63.6 \%$ of households were market participant households, as they sold maize products to market intermarries available in the study area at the time of survey; while the remaining $36.4 \%$ households did not participate in selling of maize products.

As the survey result indicated, Land is perhaps the single most important resource, as it is a base for any economic activity especially in rural and agricultural sector. Farm size influences households' decision to participate or not to participate in maize market. It also influences level of participation. Hence, land holding was hypothesized to have positive and significant relationship with participation of maize market. In this study, the average land holding for maize of sample population was found to be 0.32 ha with standard deviation of 0.1943 ha. There was a significant mean difference of the results of $t$-test with value of $t=-3.679$ and $\mathrm{P}=0.0003$. This implied that there was statistically significant mean difference among participant categories at $1 \%$ probability level. Hence farmers with large land holding were more likely to participate in the market.

In rural context, oxen ownership is an important indicator of household's wealth position. The number of oxen owned by a farmer was hypothesized to be positively related to the decision and extent of maize market participation. This is due to the fact that producers who own oxen are more likely to till in time than producers who own no oxen. Hence, a household with large oxen ownership can have good access for more production and it is one of the main resources for ploughing their land timely so as to increase marketed surplus of maize production. In this study, the average oxen ownership of sample population was found to be 1 with standard deviation of 0.855 . The t-test result shown that there 
was a significant mean difference among participant category in oxen ownership at $5 \%$ significant level $(\mathrm{t}=-2.537$, $\mathrm{p}=0.012$ ). It has shown that oxen ownership difference determines decision and level of participation of household heads. According to Table 3 the mean number of oxen was nearly 1 and 2 with standard deviation of 0.773 and 0.876 for non participant and participant category respectively.

Access to market is a determinant of profitability and sustainability of agricultural produce. Respondents in the study area reported that they sold some of their agricultural products soon after harvest to cover costs of farm inputs, social obligation and urgent family expenses by taking to the immediate nearby local market. Most of the sample farmers have to walk a long distance from home to the nearest market center to sell their agricultural products. Access to physical market infrastructure is fairly low in the villages thus farmers have to take their commodities to the District market centers. Table 3 shown that the average distance from home to the nearest market center was found to be $31.81 \mathrm{~km}$, with a standard deviation of 12.487 for sample households. And the average distance from home to the nearest development center was found to be $13.76 \mathrm{~km}$, with a standard deviation of 6.27 for sample households. It also shown that the average distance from home to the nearest all whether road was found to be $16.93 \mathrm{~km}$, with a standard deviation of 9.77 for sample households.

Prices of previous years can stimulate production of agricultural products, and thus marketed surplus for this year. In this regard if the price of maize for the last year was attractive, then production of the same crop would increase for this year and marketed surplus too. In this study lagged price was hypothesized as positive influence on participation decision. The survey result showed that the mean lagged price of maize for the sample household heads was 544.94 $\mathrm{Br}^{4} /$ quintal ${ }^{5}$ with standard deviation of 83.493.

The mean lagged price for households with participation in maize market was $542.02 \mathrm{Br}$ /quintal while the corresponding figures for the non-participant households' was $550.14 \mathrm{Br}$ /quintal with standard deviation of 86.809 and 77.841 respectively. The t-test result from Table 3 below shown that there was no significant mean difference among participant category with regard to lagged price. This shows as lagged price of maize had little influence on participation decisions.

\section{${ }^{4} 1$ Dollar $=21.95$ Birr \\ ${ }^{5} 1$ Quintal=100 Kilogram}

Price of other agricultural crops has their own influence on marketed surplus of maize. This is because an increase in price of other crops in this case wheat produced in the farm is expected to have negative effect on marketed surplus of maize. According to this study the mean price of other crops (wheat) in this case was $562.88 \mathrm{Br} /$ quintal with standard deviation of 77.786. The survey result shows that the mean price of other crops (wheat) for nonparticipant was $565.86 \mathrm{Br}$ /quintal with standard deviation of 69.092 while the corresponding figures for the participant group was
561.17Br/quintal with standard deviation of 82.64. The survey result has shown participant category was not significantly different with regard to price of other crops (wheat price) as revealed by t-test in Table 3. This implied that price of other crops had insignificant influence on participation decision.

Households within the farming community were found to depend on diverse portfolio of activities and income sources. Farmers in the study area reported that they earned income both from farm and non- farm activities. The farm income includes the sale of rain fed crops, irrigated crops and sales of livestock and its products. The non- farm activities include working as cloth, livestock and animal trading, pottery and handcraft, income earned from households' labor supplied outside their own farm plot and employ work etc. Here nonfarm activities comprises any farm activities that takes place outside own plot or farm and any off-farm activities.

The mean annual non farm incomes of sample household heads were ETB 1046.429. The mean annual non farm income for participants and non participants were ETB 1103.6 and ETB 946.4 with standard deviation of 2628.81 and 3035.84 respectively. The t-test result in Table 3 showed that there was no significant different among participant category in their level of annual non-farm income and it has shown that non- farm income had insignificant contribution for the participation decision. The details of these characteristics for the sampled households in the study areas are depicted in Table 3 below.

Table 3. Mean household characteristics by household market participation status.

\begin{tabular}{|c|c|c|c|c|}
\hline \multirow[b]{2}{*}{ Variables } & \multicolumn{2}{|c|}{ Mean value of variables for } & \multirow[b]{2}{*}{ t-value } & \multirow[b]{2}{*}{ p-value } \\
\hline & $\begin{array}{l}\text { Markets } \\
\text { Participates }\end{array}$ & $\begin{array}{l}\text { non- } \\
\text { participants }\end{array}$ & & \\
\hline Age & $\begin{array}{l}49.34 \\
(12.867)\end{array}$ & $\begin{array}{l}44.14 \\
(13.645)\end{array}$ & $-2.380 * *$ & 0.019 \\
\hline SIZ-FM & $\begin{array}{l}3.12 \\
(0.821)\end{array}$ & $\begin{array}{l}2.9 \\
(0.860)\end{array}$ & -1.520 & 0.131 \\
\hline A-MAIZE & $\begin{array}{l}0.36 \\
(0.2112)\end{array}$ & $\begin{array}{l}0.25 \\
(0.1333)\end{array}$ & $-3.679 * * *$ & 0.0003 \\
\hline OXNO & $\begin{array}{l}1.5 \\
(0.876)\end{array}$ & $\begin{array}{l}1.14 \\
(0.773)\end{array}$ & $-2.537 * *$ & 0.012 \\
\hline DS-MKT & $\begin{array}{l}30.5 \\
(12.45)\end{array}$ & $\begin{array}{l}33.63 \\
(13.47)\end{array}$ & -1.457 & 0.147 \\
\hline LAGP & $\begin{array}{l}542.2 \\
(86.809)\end{array}$ & $\begin{array}{l}550.14 \\
(77.841)\end{array}$ & $0.579)$ & 0.563 \\
\hline OTHR-PRC & $\begin{array}{l}561.17 \\
(82.639)\end{array}$ & $\begin{array}{l}565.86 \\
(69.092)\end{array}$ & 0.358 & 0.721 \\
\hline NONF-IM & $\begin{array}{l}1103.57 \\
(2628.808) \\
\end{array}$ & $\begin{array}{l}946.43 \\
(3035.844) \\
\end{array}$ & -0.337 & 0.737 \\
\hline
\end{tabular}

Source: Survey result (2016). Figures in parentheses are standard deviations.

\subsection{Determinant of Maize Farmers' Market Participation and Extent of Participation in Maize Marketing}

According to Maddala, VIF and contingency coefficient were computed. The VIF values shown in Annex 2 indicated that all the continuous explanatory variables have no serious multicollinearity problem. And the contingency coefficients computed for dummy variables were found to be no high 
degree of multicollinearity problem as shown in Annex 3. Thus, no variables were omitted. The Tobit model result is depicted in Table 3 whereas Heckman selection model result for the purpose of comparison is depicted in Annex 1 .

\subsubsection{The Tobit Model}

The result of the Heckman two step models as a comparison purpose shown in the Annex 1 is that the Inverse mill's ratio was not significant. That means estimating volume of quantity supplied without considering the decision to participate in maize marketing would not result in selection bias.

Among the variables included in the analysis, eight variables such as Sex, Age of household heads, Area of maize, Oxen number, Time of sale, Access to market information, Access to credit and Membership of cooperatives were found to be significantly influence volume of supply as it is presented under Table 4 .

Sex of household heads (SEX): Sex of household head was one of the determinants of maize market participation. Since both men and women take part in production and management of crops, previously the likely sign of the coefficient of sex on sales volume was not hypothesized. However, sex of the household head influenced the marketed surplus of maize negatively and statistically significant at less than $5 \%$ significant level. The negative sign implies that if the household is female headed the probability of maize to be marketed decreased by more than $100 \%$ which is the variation in maize market participation due to this variable. This can be explained by the fact that females have relatively lower labor (ME) advantage to produce and supply more volume. Secondly, females are less subjected to different expenditure than men's. The need of cash for less expenditure exposure made them to supply lesser volume of maize to the market. This shows that being male headed households have better access to information on marketing of maize and are more likely to adopt new marketing system than female headed households and also increase their maize production. Female headed households have not better access to information on maize marketing information and are not more likely to adopt new marketing systems than male headed.

This result agrees with Zegeye and Tesfaye, (2001) and Astatkie, (2005). The negative influence of sex was also observed in some studies which are very typical to the study area. Earlier study by Gebregzihabher, (2010) also revealed that sex of the household head is one of the factors that affect the probability of marketable supply of poultry positively in Alamata and Atsbiwomberta Woredas of Tigray.

AGE OF HOUSEHOLD HEADS (AGE): previously the likely sign of the coefficient of age on sales volume was not hypothesized since older farmers have more experience than young farmers in participating in markets in one way and/or as farmer gets older she/he may not be able to sell more of her/his produce as compared to younger farmers due to social networks fomented over a period of time. However, age of the household head influenced the marketed supply of maize positively and statistically significant at less than $1 \%$ significant level. This finding is consistent with the findings of the research conducted by Sheikhi, (2009). This explanatory variable accounted for $3.51 \%$ of the variation in maize market participation.

From this result it can be stated from the fact that those older farmer households were believed to be wise in resource use, management and due to their experience in preparation and tillage of their farm land which would increase their production level and finally their marketed surplus. Therefore as the age of sample household heads got old, the likelihood of maize market participation tends to be increased.

AREA OF MAIZE (A-MAIZE): as the result indicated the variable size of the cultivated land for maize production had positively and significantly influenced the likelihood of participation of farmers in maize market at less than $10 \%$ significance level. This explanatory variable accounted for more than $100 \%$ of the variation in maize market supply. This implied that a farmer who had relatively large plot of land can cultivate all of his land to increase surplus of his production and finally to increase his maize market participation.

The finding of the study agrees with many researches Paudel and Matsuoka, (2008); Negash, (2007) and Kudi, Bolaji et al., (2011) which showed that size of cultivated land was significant and positive to the participation study.

OXEN OWNERSHIP (OX-NO): oxen ownership had a positive and significant relationship with participation decision and extents at less than 5\% probability level. This is in line with earlier hypothesis that farmers who own oxen are more likely to till in time and thus, produce more which can be reflected on marketed supply. This explanatory variable accounted of $44 \%$ variation in maize market supply.

Evidence from the study area reflected that farmers who had more number of oxen were wealthier and had sufficient number of oxen to plough their field timely as a result of which they quickly decided to participate in the agricultural production activity. Oxen ownership was very important for farm operations. The same results were reported by Tesfaye el al., (2001); Biru, (2003) and Desale, (2008). This implies that oxen ownership has an influence on the participation decision in marketing in different areas.

TIME OF SALE (TM-SL): As the model result indicated, the variable time of sale had positively and significantly influenced the likelihood of participation of farmers in maize marketing at less than $1 \%$ significance level. This explanatory variable accounted for more than $100 \%$ of the variation in market supply of maize produce. It was as hypothesized that the producers of maize would likely earn a better price if maize market participation was immediately after harvest as compared to those farmers who supplied their produce later. This was due to the fact that supply would increase at a time when all households were planned to sell their maize products after threshing all their crops harvested and therefore price would decrease at that time.

According to the Tobit model shown in Table 3 that on average if farmers had the likelihood of participation of 
maize market immediately after harvest, price would likely increase so that volume of supply of maize would increase. The result of this study was in consistent with Aysheshm, (2007) that is time of sale affect sesame market chain analysis: the case of Metema Woreda, North Gondar Zone, Amhara National Regional State positively and significantly.

ACESS TO MARKET INFOTMATION OF HOUSE HOLD HEADS (ACCMKTI): The variable access to market information had positively and significantly influenced the likelihood of participation of maize market at less than $1 \%$ significance level. This explanatory variable accounted for more than $100 \%$ of the variation in extent of participation of farmers. From this result it can be stated that those farmers who had access to market information were more likely to participate in maize marketing than those who had no access to market information of maize. This finding was in line with the research conducted by Jane (2009) in that access to market information affects Socioeconomic Factors Influencing Smallholder Banana Farmers' Participation in Banana Farmers' Association Marketing Channel in Muranga South Distric positively and significantly.

Therefore strengthen addressing of timely and adequate information on where, how much, when and what price to sell their produce to enable them plan their production and make informed decision on their farming enterprise and comprehensive market information enables the farming community to form producer-marketing decisions so that they can timely and adequately meet the required demand.

ACCESS TO CREDIT (CRD-ACC): As the model result indicated, the variable access to and use of credit had positively and significantly influenced the likelihood of participation of maize marketing at less than $10 \%$ significance level. This explanatory variable accounted for $62.6 \%$ of the variation in extent of maize market participation. From this result it can be stated that those farmers who had access to and use formal credit were more likely to participate than those who had no access to and use formal credit. So, strengthening and expansion of credit institution in to rural area was of paramount importance to address credit needs of farming community.

This was in line with the findings of Negassa, (2009), found credit to have a positive relation with likelihood of selling raw milk in Ethiopia, indicating access to credit increased extent of milk market participation, Jerena, (2014), an analysis of factors influencing participation of smallholder farmers in red bean marketing in Halaba Special District, Ethiopia indicating access to credit positively and significantly influenced the likelihood of farmers in HSD participating in red bean market.

MEMBER OF COOPERATIVES (MBR-COP): being a cooperative society had positive influence on participation of maize market at than less 5\% level of significance. The variable accounted for $100 \%$ of the variation in extent of participation of maize marketing. Organizing of farmers to be a member of cooperative society would facilitate access to credit, access to extension information and access to market. This implied that strengthening and expansion of rural cooperatives was of paramount importance to enhance performance of maize market participation. The significant relationship between being member of a cooperative society and participation was an indication for the importance of rural financial institutions in supporting agricultural production particularly cereal farming. Cooperative members were found to be better in access to and use of credit services. This result was similar with the findings of Jane, (2009), with the title of Socio-economic Factors Influencing Smallholder Banana Farmers' Participation in Banana Farmers' Association Marketing Channel in Muranga South District.

Table 4. Maximum likelihood estimates of Tobit model.

\begin{tabular}{lllll}
\hline Variables & $\begin{array}{l}\text { Estimated } \\
\text { coefficients }\end{array}$ & $\begin{array}{l}\text { Robust Standard } \\
\text { error }\end{array}$ & t-value & $\mathbf{p}>|\mathbf{t}|$ \\
\hline SEX & -1.033137 & .4568791 & -2.26 & $0.025 * *$ \\
AGE & .0350577 & .0113657 & 3.08 & $0.002 * * *$ \\
FORML_ED & .3250637 & .3103028 & 1.05 & 0.297 \\
SIZ_FM & .081632 & .2003102 & 0.41 & 0.684 \\
A_MAIZE & 1.720087 & .9194029 & 1.87 & $0.063 *$ \\
OX_NO & .4399016 & .1994999 & 2.21 & $0.029 * *$ \\
IM_IMPT & .1370044 & .4444074 & 0.31 & 0.758 \\
DS_MKT & -.020399 & .0131057 & -1.56 & 0.122 \\
TM_SL & 1.629241 & .1954755 & 8.33 & $0.000 * * *$ \\
LAGP & -.0009597 & .0032694 & -0.29 & 0.770 \\
ACC_MKTI & 1.369885 & .3570041 & 3.84 & $0.000 * * *$ \\
OTHR_PRC & .0034264 & .0034632 & 0.99 & 0.324 \\
CRD_ACC & .625548 & .3398548 & 1.84 & $0.068 *$ \\
ACEX_SER & .0512137 & .4775236 & 0.11 & 0.915 \\
MBR_COP & 1.066009 & .4270319 & 2.50 & $0.014 * *$ \\
NONF_IM & .0000646 & .0000399 & 1.62 & 0.108 \\
cons & -5.837909 & 1.346093 & -4.34 & $0.000 * * *$ \\
\hline
\end{tabular}

Number of observations $=154 \log$ pseudo likelihood $=-199.01145$ Pseudo $\mathrm{R}^{2}=0.2689 \mathrm{~F}(16,138)=9.68$ Left-censored observations $=56$ Prob $>\mathrm{F}=$ 0.0000

Uncensored observations $=98$

Source: Model output (2016). ***, **, * represents 1\%, 5\%, 10\% significant level respectively.

\subsubsection{Effects of Changes in Significant Explanatory Variables}

All variables that were found to influence the decision and level of participation might not have similar contribution in influencing the decision of maize sellers. Hence, using a decomposition procedure suggested by Mcdonald and Moffit, (24), the results of Tobit model was used to assess the effects of changes in the explanatory variables into participation decision and intensity and the result is presented on Table 5 below.

Sex was one of the explanatory variables, which had inverse relationship with the market participation. The increased in the female headed household heads would reduce the probability of participation and intensity by $20.94 \%$ and by $56.79 \%$ respectively. This is because male headed households are believed to have the capacity to handle risks associated with marketing shocks.

Age was the other explanatory variable, which had positive relations with the market participation. The increased in one year in age of household heads would increase the probability of participation and intensity of participation by $0.83 \%$ and by $1.68 \%$ respectively. As the age 
of farmers' increases, their decision on resource allocation including time depends on the tangible and expected outputs which they thought it can bring for them. This is so because age taught them to thoroughly see the risks and benefits associated with participating in maize market.

The result also indicated that an increased in cultivated land for maize production by one hectare would increase the probability and intensity of maize market participation by $40.88 \%$ and $82.36 \%$, which were relatively large as compared to the changes resulting from other significant continuous variables. This indicated that households with more land holdings allocated more land to production of high level of maize product.

An additional oxen number put into agricultural production would increase the probability of participation in maize marketing by $10.45 \%$; increase the proportion of the sales by $21.06 \%$. This implied that oxen ownership will play a great role in farm preparation which will boost productivity and makes farmers be one participant in maize market.

The result computed also showed that the estimated increase in the probability and intensity of maize market participation resulting from time of sale of maize produce is $38.72 \%$ and $78.01 \%$ respectively. This implied that adapting the sale of maize by farmers immediately after harvest would increase a return as compared to the sale later on.

The result also showed that farmers' having access to marketing information facilities for agricultural product markets would increase the probability of participating in maize marketing by $33.11 \%$ and increase the proportion of sales by $62 \%$. This implied that the need to give emphasis to strength institutional supports to improve farmers' access to market information in order to enhance farmers' maize marketing participation.

The results computed indicated that increase in the probability and intensity of farmers' maize market participation resulting from having access to and use of credit was $14.08 \%$ and $31.6 \%$ respectively. This showed that if farmers had an opportunity to get credit, then it would be a better opportunity for participation of farmers in maize market.

The result computed also showed that the estimated increase in the probability and intensity of maize market participation resulting from membership in the primary cooperative association was $26.48 \%$ and $46.79 \%$ respectively. This implies that strengthening and promoting of cooperatives in farming community would enhance the adoption of, the accessibility and use of credit and give new information on the price of maize in agricultural commodity market.

Therefore, the study concluded that in an increase in explanatory variables, there had been certain percent increase on the probability and intensity of participation of maize marketing. As a result, maize producers have to give more emphasis to work on improving the influencing factors of maize marketing.

Table 5. Marginal effects of significant variables.

\begin{tabular}{|c|c|c|c|}
\hline Variables & $\begin{array}{l}\text { Change in probability of participation } \\
\frac{\delta \varepsilon(y *)}{\delta x i}\end{array}$ & $\begin{array}{l}\text { Change in intensity of participation(sellers) } \\
\frac{\delta \varepsilon\left(\frac{\mathrm{y} *}{\mathrm{y} *>0}\right)}{\delta x i}\end{array}$ & $\begin{array}{l}\text { Change among the whole } \\
\frac{\partial \varepsilon(y *)}{x i} \\
\delta x i\end{array}$ \\
\hline SEX & -0.2094 & -0.5679 & -1.033 \\
\hline AGE & 0.0083 & 0.0168 & 0.0351 \\
\hline A_MAIZE & 0.4088 & 0.8236 & 1.720 \\
\hline OX̄_NO & 0.1045 & 0.2106 & 0.4399 \\
\hline TM_SL & 0.3872 & 0.7801 & 1.629 \\
\hline CRD_ACC & 0.1408 & 0.3160 & 0.6256 \\
\hline MBR_COP & 0.2648 & 0.4679 & 1.066 \\
\hline
\end{tabular}

Source: Model output (2016)

\section{Conclusion and Recommendation}

\subsection{Conclusion}

Maize products do not constitute only the major food crops for the majority of the population but also as source of income at household level. The study has focused on the factors affecting the participation decisions and extent of participation of maize by households in maize marketing. The study was based on primary data from farmers and secondary data were generated from Woreda Office of Agriculture and Rural Development, Woreda Office of Trade and Transport and CSA information.

The study tried to investigate the factors influencing farmers' Decision and extent of participation behavior. The major determinant factors for maize market participation and volume of supply were estimated using Tobit model. There was variation among the producer households in the decision $\&$ level of participation. This Variation came due to different influencing factors. Attempts were made to include all theoretically important factors in the estimated model. Among the variables included in the analysis eight variables such as Sex, Age of household heads, Area of maize, Oxen number, Time of sale, Access to market information, Access to credit and Membership of cooperatives found to have significant influence on probability and intensity of participation.

\subsection{Recommendations and Policy Implications}

It is indispensable to forward policy directions based on the findings of the study to formulate strategies. Based on this understanding the following recommendations have been 
made. According to the model result, sex of the household head influenced the marketed surplus of maize negatively and statistically. Therefore, Affirmative action should be considered for gender awareness; this is done by empowering more women to engage in maize marketing.

Age of the household head influenced the volume of supply of maize statistically and positively. Government should invest in rural infrastructure; especially on the road network to ease conveyance of the maize old producer from the area of production to marketing point so that farmers can easily participate in maize marketing.

Maize area owned by the household affected the marketed supply of maize positively. Hence, it is recommended that the areas which are not under cultivation must be put in production of maize.

Time of sale affected volume of market supply of maize positively. Hence, it is recommended that farmers should sell their produce immediately after harvest to increase their income with better price.

The level of maize marketed surplus analysis result indicated that the numbers of oxen owned by household heads were directly proportional to the volume of maize supply. Hence, there is a need to promote the availability of Oxen in the District through popularizing improved species of livestock.

There should be a strong emphasis on creating good market networks and linking farmers to reliable markets information. Both government and non-government actors should invest on linking farmers to different information sources to enhance farmers' access to information on price, good tillage practices, and market demand.

Membership in primary cooperatives had significant and positive influence on extent of maize market participation. According to this result concerned officials should give emphasize on increasing awareness of farmers about advantages of being membership in cooperative associations and should Strength cooperatives and their unions.

According to the model result access to credit service had significant and positive influence on extent of maize market participation. Improving access to credit for farmers should therefore be a priority for improving maize market performance, in turn, increasing efficiency and improving consumers' welfare.

\section{Conflict of Interest}

The author has not declared any conflict of interest.

\section{References}

[1] MoFED (2012/13). Annual Report The overall economic performance of Ethiopia, Addis Ababa, Ethiopia.

[2] Global Information and Early Warning System (GIEWS, 2011). Food and Agriculture Organization Ethiopia Country Programming Framework; 2012-2015.

[3] CSA (2013). Ethiopian Agricultural Sample Survey. Addiss Ababa Vo. I.
[4] BOFED (2009). (Bureau of Finance and Economic Development), Major Growth Corridors for the Amhara Region (un published), Bair Dar, Ethiopia.

[5] BOARD (2007). (Bureau of Agriculture and Rural Development), Post-harvest evaluation report of 2006, Bahir-Dar.

[6] CSA (2013). Ethiopian Agricultural Sample Survey. Addiss Ababa, Ethiopia Vo. I.

[7] Astatkie L, Belayneh L, Elias Z (2012). Economic impacts of triticale (XTriticosecale Wittmack) adoption: The case of FARTA WEREDA, Ethiopia, and Research paper.

[8] PEDD (2007). South Gondar Administrative Zone Planning and Economic Development Department annual statistical abstract, Debre Tabor Ethiopia. 250p.

[9] CSA (2012). Ethiopian Agricultural Sample Survey. Addiss Ababa, Ethiopia Vo. I.

[10] PEDD (2002). South Gondar Administrative Zone Planning and Economic Development Department annual statistical abstract, Debre Tabor Ethiopia. 250p.

[11] OoARD (2014). (Office of Agriculture and Rural Development), Socio -Economic Survey report.

[12] Amhara Regional State (2012). Amhara Livelihood Zone Reports. South Gondar Administrative Zone Livelihood Profile, Bahir Dar.

[13] Mequanint D (2010). Assessment of Forestry and Agroforestry Extension Package Implementation Trends in Amhara Region". The case of Farta District, South Gondar Zone, Ethiopia. MSc Thesis Presentd to the College of Development Studies.

[14] Yamane T (1967). Statistics: An Introductory Analysis, 2nd Ed., New York: Harper and Row.

[15] OoARD (2015). Farta woreda (Office of Agriculture and Rural Development), Socio -Economic Survey report.

[16] Aweke M (2013). Factors influencing Adoption of Improved Maize varieties: the case of Goro- Gutu Woreda of Eastern Hararghe, Ethiopia, M. Sc Thesis. Haramaya University.

[17] Long S (1997). Regression models for Categorical and limited dependent Variables. Sage Publications, Inc. London. 35-83p.

[18] Heckman J. J (1979). Sample selection bias as a specification error, Econometric. 47, 153-161.

[19] Tobin J (1958). "Estimation of Relationships for Limited Dependent Variables", Econometrics Vol. 26 pp 24-36.

[20] Maddala G. S (1983). Limited Dependent and Qualitative variables in Econoetrics. Econometric Society Monographs No. 3. Cambridge University Press, USA pp 401.

[21] Amemiya T. (1985). Advanced Econometrics. Basil Blackwell limited UK pp 521.

[22] Maddala G. S (1997). Limited Dependent and Quantitative Variables in Econometrics. Cambridge University Press.

[23] Johnston J, J Dandiro (1997). Econometrics Methods, fourth Edition, New York: McGraw Hill Companies, Inc.

[24] Mcdonald J. F, R. A. Moffit (1980). The uses of Tobit Analysis." Review of Economics and Statistics 62 (2): 318-321. 